\title{
SCH 42137, A NOVEL ANTIFUNGAL ANTIBIOTIC FROM \\ AN Actinoplanes sp. \\ FERMENTATION, ISOLATION, STRUCTURE AND BIOLOGICAL PROPERTIES
}

\author{
R. Cooper ${ }^{\dagger}$, I. Truumees, I. Gunnarsson, D. LoebenberG, \\ A. Horan, J. Marquez, M. Patel and V. Gullo \\ Microbial Products, Schering-Plough Research, \\ M. Puar, P. Das and S. Mittelman \\ Molecular Spectroscopy, Schering-Plough Research, \\ 60 Orange Street, Bloomfield, NJ 07003, U.S.A. \\ (Received for publication August 27, 1991)
}

\begin{abstract}
A novel polycyclic xanthone, Sch 42137 , related to the albofungin family of compounds was isolated from culture broth. Its structure was determined by detailed spectroscopic studies and comparison of circular dichroic studies to related compounds albofungin and simaomicin. Sch 42137 exhibited MIC values $<0.125 \mu \mathrm{g} / \mathrm{ml}$ against yeasts and dermatophytes. Details are presented herein.
\end{abstract}

In the course of our screening for antifungal compounds from fermentation culture broths, Sch 42137 was isolated from the broth of an actinomycete identified as an Actinoplanes sp. SCC 1906 and shown by spectroscopy to be a novel polycyclic xanthone, related to the albofungin family of compounds. Details of the fermentation, isolation and spectroscopic data leading to the structure determination of these novel antifungal compounds and their biological properties are presented.

\section{Experimental}

The Microorganism

The producing culture was isolated from a Brazilian soil sample using the procedure of MAKKAR and Cross. ${ }^{1)}$ The culture was deposited in the Schering Central Culture Collection as SCC 1906. The source material for tests was frozen $\left(-80^{\circ} \mathrm{C}\right)$ preparations of a pure culture of SCC 1906. Morphological observations were made on plates of water agar, inorganic salts - starch agar (ISP4) and yeast extract malt extract agar (ISP2). Plates were incubated at $28^{\circ} \mathrm{C}$ and observed for 14 to 21 days. Whole cell analysis was by the method of LECHEVALIER. ${ }^{2)}$

A $5 \%$ inoculum of frozen whole broth of the producing organism, SCC 1906, was transferred to $50 \mathrm{ml}$ of germination medium consisting of beef extract $0.4 \%$, Tryptone $0.5 \%$, yeast extract $0.5 \%$, Cerelose $0.1 \%$, potato starch $2.4 \%, \mathrm{CaCO}_{3} 0.2 \%$, and antifoam $0.1 \%$ in a $250-\mathrm{ml}$ Erlenmeyer flask. After incubation at $30^{\circ} \mathrm{C}$ for 48 hours on a rotary shaker at $300 \mathrm{rpm}, 25 \mathrm{ml}$ of this first seed stage was transferred to a second stage containing $350 \mathrm{ml}$ of the same medium and incubated as before. After 48

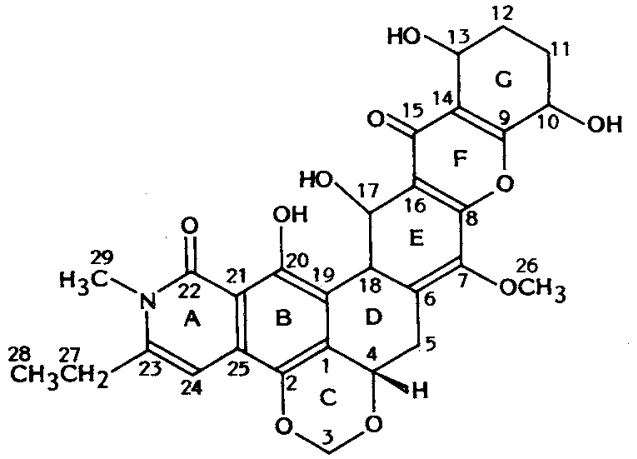

$\operatorname{Sch} 42137(1)$

† Present address: Sterling Winthrop Inc., 25 Great Valley Parkway, Malvern, Pa. 19355, U.S.A. 
hours, $25 \mathrm{ml}$ of this stage was inoculated into $350 \mathrm{ml}$ of fermentation medium consisting of potato dextrin $2 \%$, cotton seed flour $0.74 \%$, grounded peas $0.25 \%$, molasses $0.5 \%$, maltose $0.5 \%$ in a 2 -liter flask. The $\mathrm{pH}$ of the medium was adjusted to 7.2 before the addition of $\mathrm{CaCO}_{3}, 0.2 \%$. The fermentation was incubated at $30^{\circ} \mathrm{C}$ on a rotary shaker at $300 \mathrm{rpm}$ for 4 days. Activity was monitored by agar diffusion assay with Candida albicans Wisconsin as the test organism.

Ten-liter fermentations were carried out in 14-liter New Brunswick Scientific fermenters using the same fermentation medium described above. The second stage germination $(3.5 \%)$ was used to initiate fermentation which was conducted at $30^{\circ} \mathrm{C}$ for 4 days with 4 liters/minute of air and $400 \mathrm{rpm}$ agitation. The $\mathrm{pH}$ and dissolved oxygen levels were continuously monitored without adjustment during the entire fermentation by means of submerged probes. Microbial growth was determined by packed cell volume and bioactivity by agar diffusion assay as previously described.

\section{Isolation of $1,2,3$}

Filtered broth (4 liters) was adjusted to $\mathrm{pH} 2$ with $\mathrm{HCl}$ and the antifungal complex extracted with EtOAc to yield $800 \mathrm{mg}$ crude oil. This oil was chromatographed on a Sephadex LH-20 column $(2.5 \times 100 \mathrm{~cm})$ eluting with $\mathrm{CH}_{2} \mathrm{Cl}_{2}-\mathrm{MeOH}(9: 1)$. Bioactive fractions were pooled to yield $100 \mathrm{mg}$ yellow solid. This mixture was chromatographed on Sephadex LH-20 $(1.1 \times 100 \mathrm{~cm}$ column $)$ eluting with $\mathrm{MeOH}$ to yield 1 , $8 \mathrm{mg}$, as a yellow solid (Scheme 1).

From tank fermentations, filtered broth (60 liters) was adjusted to $\mathrm{pH} 2$ with $\mathrm{HCl}$, followed by EtOAc extraction. The crude mixture was chromatographed on a MCI gel CHP20P, 75 150 $\mu \mathrm{m}$ (Mitsubishi Industries), $2.5 \times 100 \mathrm{~cm}$ column eluting with a gradient of 0 to $100 \% \mathrm{CH}_{3} \mathrm{CN}$ in $\mathrm{H}_{2} \mathrm{O}$. Active fractions were pooled, yielding $1 \mathrm{~g}$ crude mixture, further chromatographed on Sephadex LH-20 $(2.5 \times 100 \mathrm{~cm}$ column) eluting with $\mathrm{MeOH}$ to yield $350 \mathrm{mg}$ yellow solid. This mixture was chromatographed on MCI gel CHP20P $37 \sim 75 \mu \mathrm{m}$, using a linear gradient of $0 \sim 100 \%$ acetone in $\mathrm{H}_{2} \mathrm{O} .1(60 \mathrm{mg})$ eluted first followed by 2 and 3 as a mixture which were separated by preparative TLC $\left(\mathrm{CH}_{2} \mathrm{Cl}_{2}-\mathrm{MeOH}, 95: 5\right)$ to give 2 $(0.5 \mathrm{mg})$ and $\mathbf{3}(1 \mathrm{mg})$ as yellow amorphous solids (Scheme 2).

\section{Spectroscopy}

All NMR spectra were obtained on a Varian XL-300 instrument. Mass spectral data were analyzed by FAB on the VG-ZAB-SE mass spectrometer at an acceleration voltage of $8 \mathrm{kV}$ and at room temperature. Spectra were obtained in both positive and negative ion modes. MIKES were recorded by focussing the parent ion with the
Scheme 1. Isolation of Sch 42137.

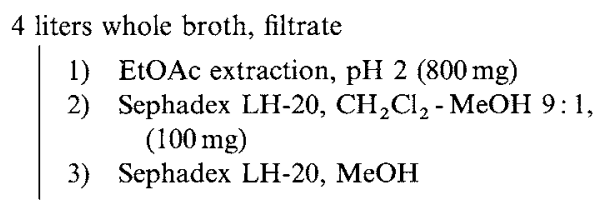

Sch 42137 (8 mg)

Scheme 2. Isolation of Sch 42137 (1) and related components 2 and $\mathbf{3}$ from 60 liters fermentation broth.

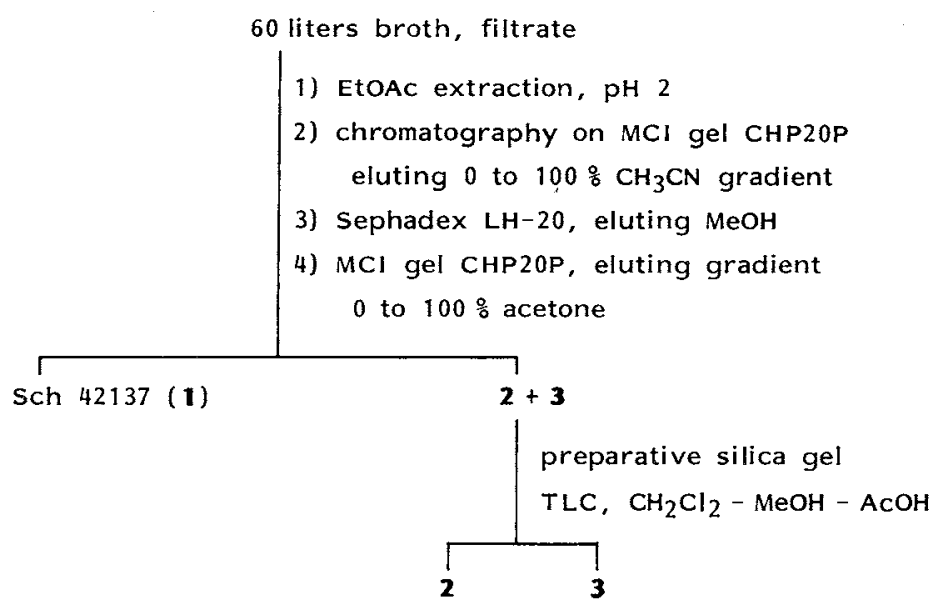


magnet, colliding it with He gas in a collision cell in the second field free region such that the main beam (parent ion) intensity was reduced to approximately $50 \%$, and energy scanning the electric sector (ESA) to collect the daughter ions. The samples were dissolved in dimethyl sulfoxide, glycerol - thioglycerol and thioglycerol alone were used as matrices in positive ion and negative ion modes, respectively. Xenon gas was used as the source of fast atoms.

$\mathrm{CD}$ spectra were recorded in $\mathrm{MeOH}$ solution at room temperature on a Jasco J600A instrument.

\section{In Vitro Antifungal Activity}

Activity was determined in microtiter minimum inhibitory concentration (MIC) tests. Media employed in these tests were Sabouraud dextrose broth(SDB),(Difco, Detroit, Mich.) and EAGLE's Minimum Essential Medium. with non-essential amino acids, L-glutamine and fetal bovine serum added (EMEM), (Whittaker Bioproducts Inc., Walkervillle, Md.). Yeasts were grown overnight in SDB at $28^{\circ} \mathrm{C}$ with shaking, and inocula adjusted in sterile saline using a spectrophotometer at $540 \mathrm{~nm}$. Mycelial fungi were grown in SDB with shaking at $28^{\circ} \mathrm{C}$ for 4 days. Compounds were serially diluted in media in 96 well microtiter plates (Falcon, Lincoln Park, NJ). SDB plates were incubated at $28^{\circ} \mathrm{C}$, and plates containing EMEM were incubated at $37^{\circ} \mathrm{C}$ under $5 \% \mathrm{CO}_{2}$ and 48 hours. MICs in SDB were defined as the lowest concentrations of drug to prevent growth or, in EMEM, the transformation from the yeast to mycelial phase of growth.

\section{Results and Discussion}

\section{The Microorganism}

The culture, SCC 1906, is a Gram-positive, filamentous organism that forms a well developed, moderately branching substrate mycelium which bears globose sporangia on distinct sporangiophores. In contact with water the sporangia dehise releasing motile, oval spores. Aerial mycelia are not formed. SCC 1906 grows well on most rich organic media, forming yellow brown to light orange vegatative mycelial pigments, and yellow to yellow brown diffusible pigments. Whole cell hydrolysates contain meso-diaminopimelic acid, galactose, glucose, mannose, arabinose, xylose, ribose, madurose and a trace of rhamnose. The producing culture is characterized as a member of the genus Actinoplanes. The culture has been deposited in the American Type Culture Collection, Rockville, Maryland under accession number ATCC 53878.

\section{Fermentation}

A typical time course for the 10 liters fermentation is shown in Fig. 1. The $\mathrm{pH}$ remained in the

Fig. 1. Fermentation profile of Sch 42137

$\square$ Dissolved oxygen, - packed cell volume, $O \mathrm{pH}, \mathbf{\square}$ antibiotic assay.

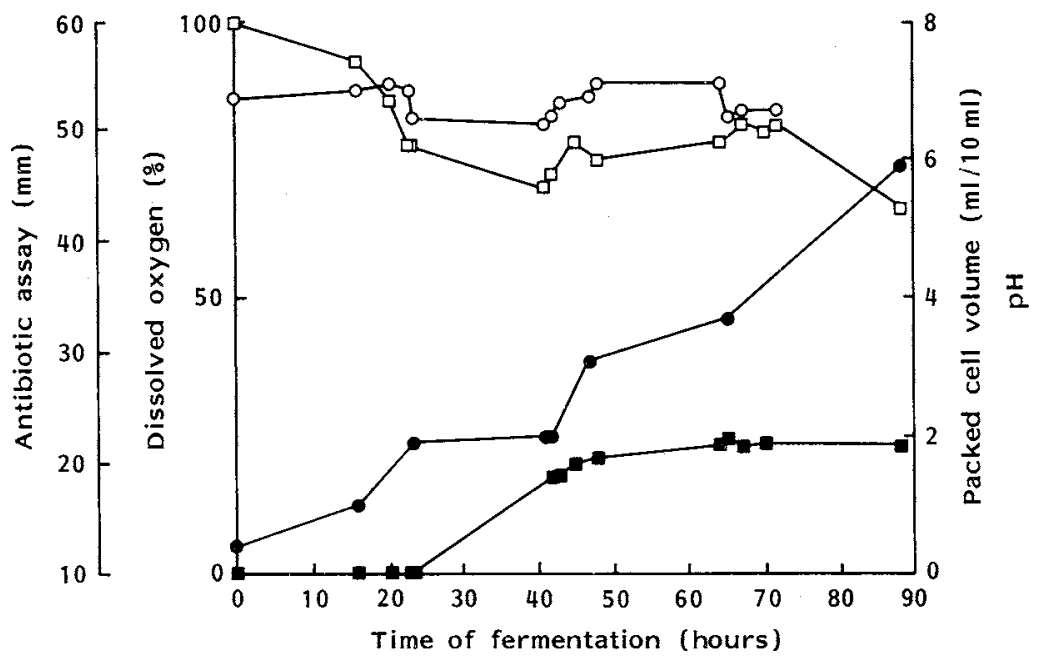


neutral range throughout the time course of the fermentation. The dissolved oxygen reached maximum utilization after 36 hours after which it remained reasonably constant indicating continued culture growth. Although microbial growth as measured by packed cell volume continued to increase throughout the monitoring period, maximum antibiotic activity was achieved after 72 hours and then remained constant.

\section{Isolation}

From a 4-liter shake flask fermentation, the culture broth was filtered and adjusted to $\mathrm{pH} 2$ (1 N $\mathrm{HCl}$ ). The bioactive component was extracted into EtOAc and further purified as outlined in Scheme 1. A yellow powder $(8 \mathrm{mg})$ was obtained after lyophilization.

In tank fermentation, three bioactive components were produced. After adjusting the filtered broth to $\mathrm{pH} 2$, these components were extracted into EtOAc, and further purified according to the steps outlined in Scheme 2. Chromatography on a MCI gel CHP20P column separated Sch 42137, 1 (60 mg, major) from $\mathbf{2}$ and $\mathbf{3}$ (minor components) which were finally separated by preparative silica TLC, and after removal of solvents, yielded yellow amorphous solids $2(0.5 \mathrm{mg})$ and $3(1.0 \mathrm{mg})$.

Physico-chemical Properties

TLC on silica gel plates developing in $\mathrm{CH}_{2} \mathrm{Cl}_{2}-\mathrm{MeOH}-\mathrm{AcOH}(93: 7: 0.005)$ revealed the presence of 1 having $\operatorname{Rf} 0.5 ; 2$, Rf 0.65 and $3, \mathrm{Rf} 0.7$. The compounds stained brown in the presence of $\mathrm{I}_{2}$ vapors and tested $\mathrm{FeCl}_{3}$ positive. HPLC of a mixture of 1, 2, 3 using a YMC C-8 column and the conditions described (Fig. 2), resulted in the separation of the three components.

\section{Spectroscopic Properties and Structures}

The IR spectrum $(\mathrm{KBr})$ of Sch 42137 indicated the presence of a hydroxyl $\left(3400 \mathrm{~cm}^{-1}\right)$, conjugated carbonyl $\left(1640 \mathrm{~cm}^{-1}\right)$ and pyrone $\left(1570 \mathrm{~cm}^{-1}\right)$ functionalities. The UV spectrum is characteristic of polycyclic xanthone related compounds, ${ }^{3,4)}$ and is shown in Fig. 3(A).

FAB mass spectral data for 1 show a protonated molecular ion $(\mathrm{M}+\mathrm{H})^{+} m / z \quad 550$, and $(\mathrm{M}-\mathrm{H})^{-} m / z 548$ in the negative mode. High resolution data corresponded to a molecular formula $\mathrm{C}_{29} \mathrm{H}_{28} \mathrm{NO}_{10}(\mathrm{M}+\mathrm{H})^{+}, 550.1713, \Delta 4 \mathrm{ppm}$. The ${ }^{1} \mathrm{H}$ NMR spectrum for 1 indicated an ethyl group and two methyl singlets at $\delta 3.50\left(\mathrm{~N}-\mathrm{CH}_{3}\right)$ and 3.85 $\left(\mathrm{O}-\mathrm{CH}_{3}\right)$. The chemical shift of $\mathrm{N}-\mathrm{CH}_{3}$ suggested a strong deshielding influence. In addition, the presence of a dioxy-methylene group $\left(\mathrm{O}-\mathrm{CH}_{2}-\right.$ O) at $\delta 5.4,5.6(\mathrm{~d}, J=6 \mathrm{~Hz})$, an ABX pattern due to a $-\mathrm{CH}_{2}-\mathrm{CH}$ moiety and a 1,2,3,4-tetrahydro, 1,4-dihydroxy benzene ring were also present in the spectrum. The addition of $\mathrm{D}_{2} \mathrm{O}$ caused the collapse of 4 signals indicating the presence of 4 exchangeable protons; two signals sharpened that were assigned to the oxymethine protons (Table 1).

Difference NOE experiments confirmed the substitution pattern of ring $\mathrm{A}$. When the $\mathrm{N}-\mathrm{CH}_{3}$
Fig. 2. HPLC profile of a mixture of 1, 2 and 3.

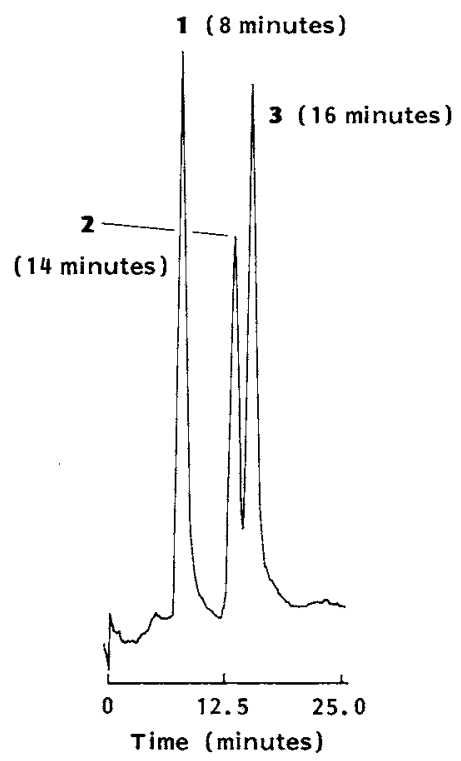

HPLC: Column: YMC C-8, $2.5 \times 30 \mathrm{~cm}$. Mobile phase: $\mathrm{CH}_{3} \mathrm{CN}-\mathrm{H}_{2} \mathrm{O}(+0.003 \% \mathrm{AcOH}), 1: 1$. Flow rate: $1.5 \mathrm{ml} /$ minute. Detection: $360 \mathrm{~nm}, 0.01 \mathrm{AuFS}$. 
Fig. 3. UV and $C D$ of albofungin related compounds.

(A) UV of Sch 42137, (B) CD of $1 \sim 5$.

(A)

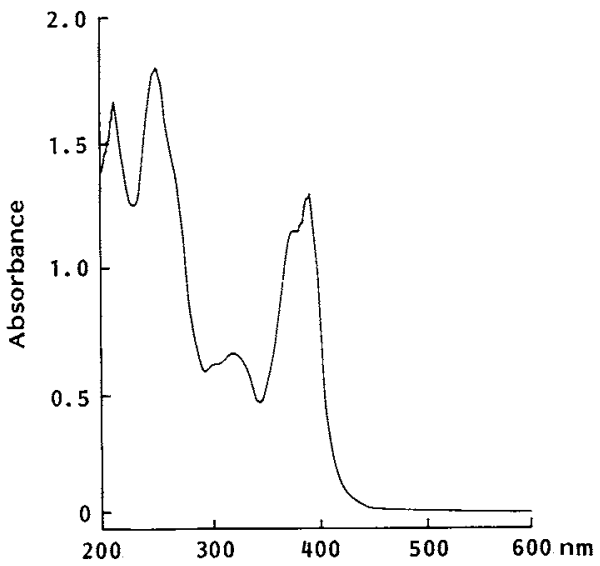

(B)

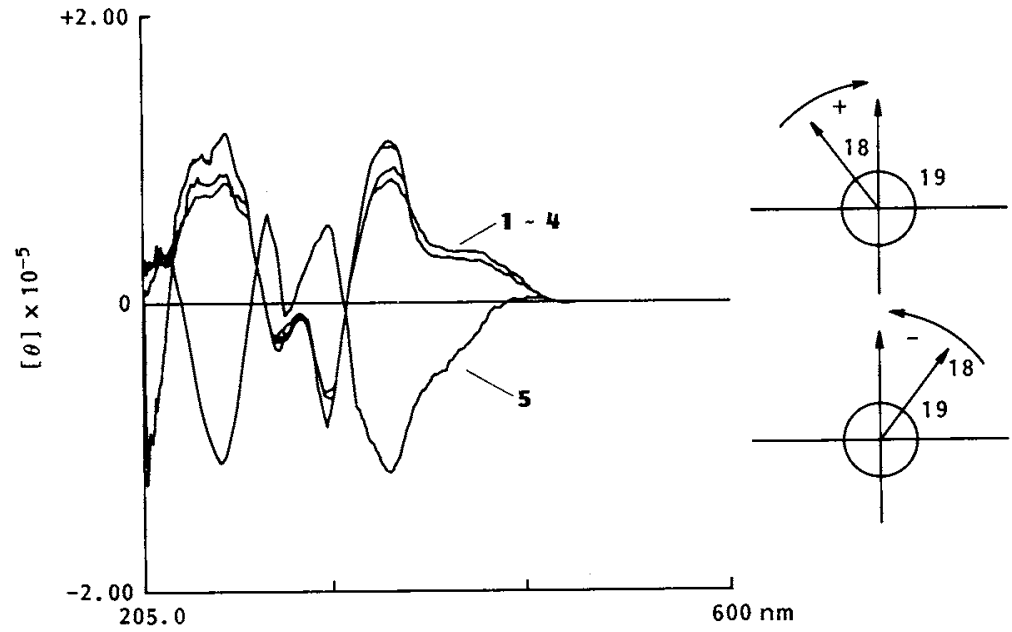

signal was irradiated, a positive NOE was observed for the aromatic $\mathrm{CH}_{3}$ and $\mathrm{CH}_{2}$ signals. In addition, when the aromatic $\mathrm{C}-\mathrm{H}$ signal was irradiated, both $\mathrm{CH}_{3}$ and $\mathrm{CH}_{2}$ signals displayed a positive NOE, indicating substitution at $\mathrm{C}-23$.

In the fully decoupled ${ }^{13} \mathrm{C}$ NMR spectrum (DMSO- $d_{6}$ ) 29 carbon signals were observed for 1. Assignments were made based on APT data and comparisons ${ }^{5,6)}$ to the related compounds, 4a, 4b (Table 2). The ${ }^{13} \mathrm{C}$ NMR spectrum confirmed the presence of three methyl $\left(\mathrm{CH}_{3}, \mathrm{NCH}_{3}, \mathrm{OCH}_{3}\right)$ and three methine carbons, the latter bearing an oxygen atom. The presence of a methylene carbon at $\delta 91.0 \mathrm{ppm}$ was consistent with the dioxy-methylene group $\left(\mathrm{O}-\mathrm{CH}_{2}-\mathrm{O}\right)$. The presence of a keto, an amide and aromatic oxygenated carbons were indicated by chemical shifts between $150 \sim 185 \mathrm{ppm}$.

FAB-MS data for both 2 and 3 were virtually identical: $(\mathrm{M}+\mathrm{H})^{+}, m / z 592, \mathrm{C}_{31} \mathrm{H}_{30} \mathrm{NO}_{11}(\mathrm{M}+\mathrm{H})^{+}$ 592.1811, 45 ppm.

${ }^{1} \mathrm{H}$ NMR data for the minor components, $\mathbf{2}$ and $\mathbf{3}$, indicated the addition of one acetate group to 
Table 1. ${ }^{1} \mathrm{H}$ NMR data for $\mathbf{1}$ to $\mathbf{5}, \delta \mathrm{ppm}(J=\mathrm{Hz})$ downfield from TMS.

\begin{tabular}{|c|c|c|c|c|c|}
\hline $\begin{array}{c}\text { Sch } 42137(\mathbf{1}) \\
\text { DMSO- } d_{6}\end{array}$ & $\stackrel{2}{\text { DMSO- } d_{6}}$ & $\begin{array}{c}3 \\
\text { DMSO- } d_{6}\end{array}$ & $\begin{array}{c}\text { LL-D42067 } \\
\qquad(4 \mathrm{a})^{5)} \\
\mathrm{CDCl}_{3}-\mathrm{DMSO}-d_{6}\end{array}$ & $\begin{array}{c}\text { LL-D } 42067 \beta \\
(4 \mathbf{b})^{5)} \\
\mathrm{CDCl}_{3}\end{array}$ & $\begin{array}{l}\text { Albofungin (5) } \\
\text { DMSO- } d_{6}\end{array}$ \\
\hline $1.26 \mathrm{t},(7) 3 \mathrm{H}$ & $1.26 \mathrm{t},(7) 3 \mathrm{H}$ & $1.26 \mathrm{t},(7) 3 \mathrm{H}$ & $1.88 \mathrm{~m}, 2 \mathrm{H}$ & $1.88 \mathrm{~m}, 2 \mathrm{H}$ & $1.8 \mathrm{~m}, 2 \mathrm{H}$ \\
\hline $1.74 \mathrm{br}, 2 \mathrm{H}$ & $1.8 \sim 1.95 \mathrm{~m}$ & $1.8 \sim 1.95 \mathrm{~m}$ & $2.34 \mathrm{~m}, 2 \mathrm{H}$ & $2.30 \mathrm{~m}, 2 \mathrm{H}$ & $2.05 \mathrm{~m}, 2 \mathrm{H}$ \\
\hline $1.95 \mathrm{tr},(14,14)$ & $2.0 \mathrm{~s}, 3 \mathrm{H}$ & $2.1 \mathrm{~s}, 3 \mathrm{H}$ & & & \\
\hline $2.2 \operatorname{tr}, 1,14,14$ & & & $\begin{array}{l}2.45 \mathrm{~s}, 3 \mathrm{H} \\
2.58 \mathrm{~m}, 1 \mathrm{H}\end{array}$ & $\begin{array}{l}2.38 \mathrm{~s}, 3 \mathrm{H} \\
2.57 \mathrm{~m}, 2 \mathrm{H}\end{array}$ & \\
\hline $2.5 \mathrm{dd},(13,13) 1 \mathrm{H}$ & $2.5 \mathrm{~m}$ & $2.5 \mathrm{~m}$ & & & \\
\hline $2.82 \mathrm{q}$, (7) $2 \mathrm{H}$ & $2.82 \mathrm{q},(7) 2 \mathrm{H}$ & $2.82 \mathrm{q},(7) 2 \mathrm{H}$ & $3.62 \mathrm{~s}, 3 \mathrm{H}$ & $\ldots$ & $2.82 \mathrm{tr},(5,13) 1 \mathrm{H}$ \\
\hline $3.5 \mathrm{~s}, 3 \mathrm{H}$ & $3.5 \mathrm{~s}, 3 \mathrm{H}$ & $3.5 \mathrm{~s}, 3 \mathrm{H}$ & $\begin{array}{l}3.72 \mathrm{dd},(5,14) \\
1 \mathrm{H}\end{array}$ & $\begin{array}{l}3.69 \mathrm{dd},(5,14) \\
1 \mathrm{H}\end{array}$ & $\begin{array}{l}3.25 \mathrm{dd},(5,13) \\
1 \mathrm{H}\end{array}$ \\
\hline $3.5 \mathrm{dd},(5,13) 1 \mathrm{H}$ & $3.5 \mathrm{~m}$ & $3.5 \mathrm{~m}$ & $3.88 \mathrm{~s}, 3 \mathrm{H}$ & $3.87 \mathrm{~s}, 3 \mathrm{H}$ & $\begin{array}{c}3.35 \mathrm{~s}, 3 \mathrm{H} \\
\mathrm{Ar}-\mathrm{Me}\end{array}$ \\
\hline $3.85 \mathrm{~s}, 3 \mathrm{H}$ & $3.87 \mathrm{~s}, 3 \mathrm{H}$ & $3.85 \mathrm{~s}, 3 \mathrm{H}$ & $4.55 \mathrm{~s}, 1 \mathrm{H}$ & $4.79 \mathrm{~m}, 1 \mathrm{H}$ & $3.65 \mathrm{~s}, 3 \mathrm{H} \mathrm{OMe}$ \\
\hline $4.51 *$ br, $1 \mathrm{H}$ & $4.5 \mathrm{~m}, 1 \mathrm{H}$ & $4.65 \mathrm{~m}, 1 \mathrm{H}$ & $4.80 \mathrm{~m}, 2 \mathrm{H}$ & $\begin{array}{l}4.81 \mathrm{dd},(5,13) \\
\quad 1 \mathrm{H}\end{array}$ & $4.4 \mathrm{tr},(6) 1 \mathrm{H}$ \\
\hline $4.80^{*} \mathrm{br},(6,3) 1 \mathrm{H}$ & & & & & $4.8 \mathrm{br}, 1 \mathrm{H}$ \\
\hline $4.85 \mathrm{dd},(5,13) 1 \mathrm{H}$ & $4.85 \mathrm{~m}$ & $4.85 \mathrm{dd},(5,13)$ & $5.08 \mathrm{~m}, 1 \mathrm{H}$ & $5.06 \mathrm{~m}, 1 \mathrm{H}$ & $\begin{array}{l}4.95 \mathrm{dd},(5,13) \\
1 \mathrm{H}\end{array}$ \\
\hline $4.95^{* *}$ br, $1 \mathrm{H}$ & $5.15^{* *} \mathrm{~s}, \mathrm{OH}$ & & $5.32 \mathrm{~d},(6) 1 \mathrm{H}$ & $5.32 \mathrm{~d},(6) 1 \mathrm{H}$ & \\
\hline $5.40 \mathrm{~d},(6) 1 \mathrm{H}$ & $5.40 \mathrm{~d},(6) 1 \mathrm{H}$ & $5.40 \mathrm{~d},(6) 1 \mathrm{H}$ & $5.55 \mathrm{~d},(6) 1 \mathrm{H}$ & $5.53 \mathrm{~d},(6) 1 \mathrm{H}$ & $5.15^{* *} \mathrm{~d},(3) \mathrm{OH}$ \\
\hline $5.60 \mathrm{~d},(6) 1 \mathrm{H}$ & $5.60 \mathrm{~d},(6) 1 \mathrm{H}$ & $5.60,(6) 1 \mathrm{H}$ & $5.91 \mathrm{~d}, \mathrm{OH}$ & & \\
\hline $5.90^{* *} \mathrm{~d},(5) 1 \mathrm{H}$ & $5.95 \mathrm{brs}, 1 \mathrm{H}$ & $\begin{array}{l}6.1 \mathrm{~d} \\
6.7 \mathrm{~s}, 1 \mathrm{H}\end{array}$ & & & $\begin{array}{l}5.43 \mathrm{~d},(6) 1 \mathrm{H} \\
5.67 \mathrm{~d},(6) 1 \mathrm{H}\end{array}$ \\
\hline $6.7 \mathrm{~s}, 1 \mathrm{H}$ & $6.7 \mathrm{~s}, 1 \mathrm{H}$ & & $6.70 \mathrm{~s}, 1 \mathrm{H} \mathrm{Ar}-\mathrm{H}$ & $6.54 \mathrm{~s}, 1 \mathrm{H} \mathrm{Ar}-\mathrm{H}$ & $6.61 \mathrm{~s}, 1 \mathrm{H}, 7.0 \mathrm{~s}$ \\
\hline $13.2^{* *} \mathrm{~s}, \mathrm{IH}$ & & & $\begin{array}{l}12.76 \mathrm{~s}, \mathrm{OH} \\
13.58 \mathrm{~d}, \mathrm{OH}\end{array}$ & $\begin{array}{l}10.1 \mathrm{~s}, \mathrm{NH} \\
12.8 \mathrm{~s}, \mathrm{OH}\end{array}$ & $13.0 \mathrm{~s}, \mathrm{OH}$ \\
\hline $13.5^{* *} \mathrm{~s}, \mathrm{IH}$ & & & & $12.9 \mathrm{~s}, \mathrm{OH}$ & $13.0^{* *} \mathrm{~s}, \mathrm{OH}$ \\
\hline
\end{tabular}

* Sharpens/** Collapses upon addition of $\mathrm{D}_{2} \mathrm{O}$.

Spectra obtained on a Varian XL-300 instrument.

the molecule of $1\left({ }^{1} \mathrm{H}\right.$ NMR $\delta 2.0(2.05) \mathrm{s}, 3 \mathrm{H}$, and ${ }^{13} \mathrm{C}$ NMR $20(21) \mathrm{ppm}$ and 175 (175) ppm). Small changes in ring $G$ chemical shifts only in $\mathbf{2}$ and $\mathbf{3}$ were observed. The rest of the NMR data were essentially unchanged from those of 1 . We assigned the chemical shift values to the protons at $10-\mathrm{H}$ and $13-\mathrm{H}$ by comparison to ${ }^{1} \mathrm{H}$ NMR assignments for albofungin 5 from the data shown in Tables 1 and 3. Albofungin has a methoxy-substituent on $\mathrm{C}-10$. The $10-\mathrm{H}$ signal at $\delta 4.40$ in albofungin was clearly seen as a triplet, whereas the signal at $\delta 4.80$, assigned to $13-\mathrm{H}$, was seen as a broad complex due to coupling with the $\mathrm{OH}$ group. Upon addition of $\mathrm{D}_{2} \mathrm{O}$, the signal at $\delta 4.80$ collapsed to a double doublet. We then compared the 10-H, 13- $\mathrm{H}$ proton chemical shifts in $\mathbf{2}$ and $\mathbf{3}$ to $\mathbf{1}$ and $\mathbf{5}$, in order to make the assignments indicated in Table 3. In each acetylated molecule, we noticed a shift of one different proton to lower field due to acetylation $(2,10-\mathrm{H}, \delta 5.95$, and $3,13-\mathrm{H}, \delta 6.10)$.

In order to locate the position of the oxymethylene system in $\mathbf{1}$ as part of ring $\mathrm{C}$, and to assign the stereochemistry of the 4-H proton, we examined spectroscopic characteristics that would differentiate between the albofungin and LL-D42067 series of compounds. NMR, FAB mass spectroscopy and circular dichroic (CD) spectra were obtained for albofungin, LL-D42067 and 1 and a comparison of the data is presented below. Although some minor NMR chemical shift differences between albofungin and 1 were apparent, CD studies on these compounds enabled us to establish the stereochemistry of 1 .

Interpretation of only the NMR data for 1 could have led to an ambiguous stereochemical assignment 
Table 2. ${ }^{13} \mathrm{C}$ NMR data for $\operatorname{Sch} 42137$ (1) and related compounds.

\begin{tabular}{|c|c|c|c|c|}
\hline $\begin{array}{l}\text { Carbon } \\
\text { type }\end{array}$ & $\begin{array}{l}\text { Sch } 42137(1) \\
\text { DMSO- } d_{6}\end{array}$ & $\begin{array}{c}\text { LL-D } 42067 \alpha(\mathbf{4 a}) \\
\text { DMSO- } d_{6}\end{array}$ & $\begin{array}{l}\mathrm{LL}-\mathrm{D} 42067 \beta(\mathbf{4 b}) \\
\mathrm{CD}_{3} \mathrm{OD}-\mathrm{CDCl}_{3}\end{array}$ & $\begin{array}{l}\text { Albofungin (5) } \\
\text { DMSO- } d_{6}\end{array}$ \\
\hline $\mathrm{CH}_{3} / \mathrm{CH}_{2}$ & $11.5 / 24.8$ & 20.4 & 19.1 & 18.0 \\
\hline $\mathrm{CH}_{2}$ & 25.0 & 25.4 & 25.9 & 22.7 \\
\hline $\mathrm{CH}_{2}$ & 25.2 & 25.8 & 26.9 & 27.8 \\
\hline $\mathrm{CH}_{2}$ & 28.5 & 29.0 & 29.7 & - \\
\hline $\mathrm{N}-\mathrm{CH}_{3}$ & 29.4 & 30.4 & - & 36.8 \\
\hline $\mathrm{CH}$ & 57.9 & 58.5 & 62.0 & 57.5 \\
\hline $\mathrm{OCH}_{3}$ & 61.0 & 61.6 & 62.2 & 58.7 \\
\hline $\mathrm{CH}$ & 62.5 & 63.3 & 65.0 & 72.0 \\
\hline $\mathrm{CH}$ & 71.0 & 71.7 & 72.8 & 74.6 \\
\hline $\mathrm{CH}_{2}$ & 91.0 & 90.4 & 91.1 & 90.5 \\
\hline $\mathrm{Ar}-\mathrm{CH}$ & 97.3 & 100.0 & 100.1 & 105.1 \\
\hline $\mathrm{C}$ & 108.2 & 109.2 & 110.5 & 109.0 \\
\hline $\mathrm{C}$ & 109.2 & 109.7 & 110.6 & 109.6 \\
\hline $\mathrm{C}$ & 110.6 & 111.0 & 111.7 & 111.5 \\
\hline $\mathrm{C}$ & 113.2 & 113.7 & 114.7 & 112.7 \\
\hline $\mathrm{C}$ & 118.5 & 119.0 & 119.2 & 113.8 \\
\hline $\mathrm{C}$ & 125.2 & 126.6 & 128.8 & 130.0 \\
\hline $\mathrm{C}$ & 134.5 & 134.9 & 136.1 & 130.2 \\
\hline $\mathrm{C}$ & 134.7 & 135.3 & 136.3 & 136.2 \\
\hline $\mathrm{C}$ & 135.5 & 136.1 & 137.0 & 140.3 \\
\hline $\mathrm{C}$ & 145.4 & 141.3 & 138.1 & 141.6 \\
\hline $\mathrm{C}$ & 147.4 & 147.9 & 148.9 & 142.6 \\
\hline $\mathrm{C}$ & 150.6 & 151.1 & 151.9 & 149.4 \\
\hline $\mathrm{C}$ & 151.9 & 152.5 & 153.0 & 156.7 \\
\hline $\mathrm{C}$ & 164.8 & 165.4 & 165.3 & 163.2 \\
\hline $\mathrm{C}$ & 165.1 & 165.6 & 167.2 & 165.0 \\
\hline $\mathrm{C}$ & 182.0 & 182.3 & 183.6 & 182.0 \\
\hline
\end{tabular}

$\delta$ in ppm downfield from TMS, spectra obtained on a Varian XL-300 instrument.

Table 3. ${ }^{1} \mathrm{H}$ NMR values for the ring $\mathrm{G}$ in $\mathbf{1}, \mathbf{2}, \mathbf{3}$ and 5 .

\begin{tabular}{clllll}
\hline $\mathrm{R}_{2} \mathrm{O}-\mathrm{C}(13) \mathrm{H}-\mathrm{C}(12) \mathrm{H}_{2}-\mathrm{C}(11) \mathrm{H}_{2}-\mathrm{C}(10) \mathrm{H}-\mathrm{OR} \mathrm{R}_{3}$ & $10-\mathrm{H}$ & \multicolumn{1}{c}{$13-\mathrm{H}$} & $\mathrm{OH}$ & $\mathrm{OH}$ \\
\hline $\mathbf{1}$ & $\mathrm{R}_{2}=\mathrm{R}_{3}=\mathrm{H}$ & $4.51^{*} \mathrm{br}$ & $4.80^{*} \mathrm{br}$ & $5.90^{* *}$ & $4.95^{* *}$ \\
& & & $(J=6,3 \mathrm{~Hz})$ & & \\
$\mathbf{2}$ & $\mathrm{R}_{2}=\mathrm{H}, \mathrm{R}_{3}=\mathrm{Ac}$ & $5.95 \mathrm{br}$ & $4.85^{*} \mathrm{~m}$ & - & $5.15^{* *}$ \\
$\mathbf{3}$ & $\mathrm{R}_{2}=\mathrm{Ac}, \mathrm{R}_{3}=\mathrm{H}$ & $4.65^{*} \mathrm{~m}$ & $6.10 \mathrm{~m}$ & $5.15^{* *}$ & - \\
$\mathbf{5}$ & $\mathrm{R}_{2}=\mathrm{H}, \mathrm{R}_{3}=\mathrm{CH}_{3}$ & $4.40 \mathrm{tr}$ & $4.80 \mathrm{br}$ & $5.15^{* *} \mathrm{~d}$, & - \\
& & & $(J=6 \mathrm{~Hz})$ & $(J=3 \mathrm{~Hz})$ & \\
\end{tabular}

* Sharpens/** Collapses upon addition of $\mathrm{D}_{2} \mathrm{O}$.

$\delta$ in ppm downfield from TMS, spectra obtained on a Varian XL-300 instrument.

of the 4-H proton. In order to assign stereochemistry, we used CD studies. In general large absolute circular dichroism is associated with an allowed electric dipole transition. In a planar chromophore such a transition gives rise to a linear charge displacement but in a corresponding dissymetric chromophore, such as 1, it produces a helical charge displacement which has a linear and a circular component i.e., an electric and magnetic moment. The sign and the magnitude of the circular dichroism is directly related to the stereochemistry of the dissymetric chromophore, thus the absolute configuration on the molecule containing the chromophore may be determined. It is however necessary to locate (1) the polarization direction of the transition and (2) the location and orientation of the transition dipoles in the molecule. The coupling of the two chromophores in the dissymetric molecule (the exciton chirality method) ${ }^{7}$ gave 
rise to Cotton effects. The xanthone ring in albofungin is in an inverted arrangement with respect to LL-D42067. This is reflected by the stereochemistry of the 4-H proton in albofungin and in LL-D42067. We thus made a comparison of $1,2,3,4 a$ (LL-D42067, the structure of which had been obtained by X-ray ${ }^{6)}$ ) and 5 (albofungin). The results of the CD study are shown in Fig. 3(B) and Table 4. Compounds 1 4 showed identical CD spectra, whereas the spectrum of $\mathbf{5}$ was clearly opposite. The opposite sign curves also correlate very well with the optical rotation data (see Fig. 4). Since it had been established by X-ray ${ }^{6}$ that LL-D42067 $\alpha$ had the 4-H equatorial configuration and the $\mathrm{CD}$ curves for $1 \sim 4$ were the same, therefore the stereochemistry at $4-\mathrm{H}$ for $\mathbf{1}$, (and the two minor components, 2,3 ) was assigned similarly to LL-D42067 $\alpha \mathbf{( 4 a )}$. In albofungin, $4-\mathrm{H}$ is axial. ${ }^{8,9}$ ) Although no X-ray data are available for this compound, a CD spectrum has been published ${ }^{9)}$ which agrees with our results. Furthermore, an $\mathrm{X}$-ray structure for the related compound, lysoli-

Table 4. CD studies on Sch 42137 (1) and related compounds.

\begin{tabular}{lccc}
\hline \multirow{2}{*}{ Sample } & MW & \multicolumn{2}{c}{ Concentration } \\
\cline { 2 - 4 } & & $\mathrm{mg} / 100 \mathrm{ml}$ & $\mathrm{M}$ \\
\hline Sch 42137 (1) & 549 & 0.566 & $1.03 \times 10^{-5}$ \\
$\mathbf{2}$ & 591 & 0.588 & $1.05 \times 10^{-5}$ \\
$\mathbf{3}$ & 591 & 0.542 & $9.87 \times 10^{-6}$ \\
LL-D42067 $\alpha$ (4a) & 535 & 0.581 & $1.09 \times 10^{-5}$ \\
Albofungin (5) & 520 & 0.503 & $9.67 \times 10^{-6}$ \\
\hline
\end{tabular}

Fig. 4. Structures and optical rotation data for albofungin and related xanthone compounds.

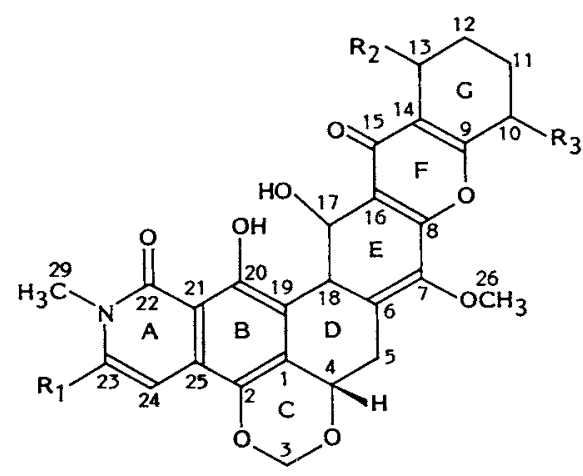

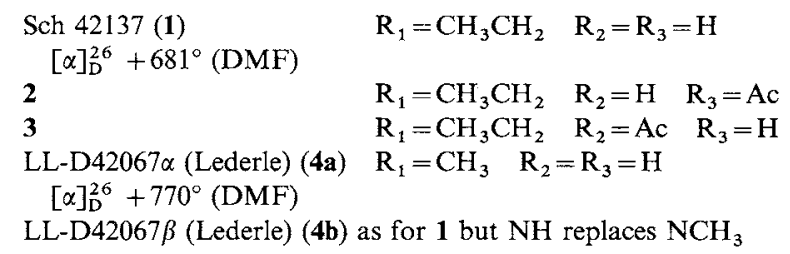<smiles></smiles>

Albofungin (Pfizer) (5) $[\alpha]_{\mathrm{D}}^{26}-670^{\circ}(\mathrm{DMF})$<smiles>COc1c(Cl)ccc2c(=O)c3c(O)c4c5c(c3oc12)OCOC5C(OC)c1cc2c(c(O)c1-4)C(=O)N(C)C(OC)C2O</smiles>

Lysolipin I (6) $[\alpha]_{\mathrm{D}}^{26}-50^{\circ}\left(\mathrm{CHCl}_{3}\right)$ 
$\operatorname{pin}^{10)}(6)$ has been made. The $[\alpha] 26^{\circ} \mathrm{C}$ value for 6 is clearly different from albofungin; the stereochemistry at 4-H is reversed and is now similar to 1 and LL-D42067 $\alpha$.

The positive ion FAB-MS of both 1 and albofungin generated strong $(\mathrm{M}+\mathrm{H})^{+}$ions although fragmentation patterns were weak in both cases. Only fragment ions corresponding to losses of $\mathrm{H}_{2} \mathrm{O}$, $\mathrm{C}_{2} \mathrm{H}_{5}, \mathrm{CH}_{3} \mathrm{O}$, and $\left(\mathrm{CH}_{3} \mathrm{O}+\mathrm{OCH}_{2} \mathrm{O}\right)$ from 1 , and similar losses from albofungin, were of any significance.

In the negative ion FAB-MS of 1 and albofungin, strong $(\mathrm{M}-\mathrm{H})^{-}$ions were obtained in each case at $m / z 548$ and 519, respectively. Only losses of the ring substituents produced fragments of any significance.

CAD MIKES $^{11)}$ were recorded on $m / z 550$ from 1 and $m / z 521$ from albofungin (5) in the positive ion mode. Two daughter ions arising from losses of 18 and 30 a.m.u. from the $(\mathrm{M}+\mathrm{H})^{+}$ions were clearly observed in both the compounds. The next daughter ion corresponded to a loss of 48 a.m.u., whereas it was 50 a.m.u. (with very small 48) in the case of albofungin. This difference may be explained on the basis of the loss of $\left(\mathrm{CH}_{3} \mathrm{O}+\mathrm{OH}\right)$ in the case of 1 and $\left(\mathrm{NH}_{2}+2 \mathrm{OH}\right)$ in albofungin. This criterion, although small, may be used to differentiate molecules possessing an $\mathrm{NH}_{2}$ group. In the negative ion FAB MIKES on $m / z 548$ from 1 and $m / z 519$ from albofungin, fragmentation was weak, with only losses of 17 and 30 a.m.u. being of any importance. The objective of performing CAD MIKES was to observe whether the effect of collision with a neutral gas on the parent ion (in either positive or negative mode) could generate (a) more intense fragmentation and/or (b) any difference in the fragmentation pattern or intensity of the two molecules which would enable us to distinguish between them. It may be surmised from the MIKES investigation that the collision activated dissociation of the two compounds are quite similar apart from the noted exception.

\section{Biological Properties}

The antifungal activity of Sch 42137 (1) against various yeasts and dermatophytes is shown in Table 5. Sch 42137 was very active (MICs $<0.125 \mu \mathrm{g} / \mathrm{ml}$ ) against yeasts and dermatophytes. Both Sch 42137 and albofungin were slightly more active than LL-D42067. However in EMEM medium, the activity of Sch 42137 was similar to LL-D42067 and both were much less active than albofungin. No antifungal data were previously reported for LL-D42067 although LL-D42067 4a (and b) are reportedly ${ }^{5,6}$ effective for controlling coccidiosis caused by Eimeria species in poultry and cattle.

\section{Conclusion}

Novel polycyclic xanthone antibiotics have been reported for culture broths of Streptomyces,

Table 5. In vitro activity of Sch 42137 (1), 2 and 3 and related compounds against various fungi.

\begin{tabular}{|c|c|c|c|c|}
\hline & \multicolumn{4}{|c|}{ Geometric mean MICs $(\mu \mathrm{g} / \mathrm{ml})$ in various media } \\
\hline & Sch $42137(\mathbf{1})$ & 2,3 & LL-D42067 (4) & Albofungin (5) \\
\hline$Y(\mathrm{SDB})(12)$ & $<0.125$ & 2 & 0.125 & $<0.125$ \\
\hline $\mathrm{D}(\mathrm{SDB})(7)$ & $<0.125$ & 1 & 0.5 & $<0.125$ \\
\hline $\mathrm{Y}(\mathrm{EMEM})(9)$ & 16 & 8 & 32 & $<0.125$ \\
\hline \multicolumn{5}{|c|}{$\begin{array}{l}\mathrm{Y}=\text { Yeast }(\mathrm{SDB})=6 \text { strains } \text { Candida albicans; } 2 \text { each } C . \text { tropicalis, } \text { C. stellatoidea, } C \text {. parapsilosis } \\
\mathrm{Y}=\text { Yeast }(\mathrm{EMEM})=6 \text { strains } C . \text { albicans, } 2 \text { C. tropicalis, } 1 \text { C. stellatoidea. } \\
\mathrm{D}=\text { Dermatophytes }(\mathrm{SDB})=2 \text { strains each Trichophyton mentagrophytes, } T . \text { rubrum, } T . \text { tonsurans } \\
\text { Microsporon canis. } \\
\text { EMEM = EAGLE's minimum essential medium, pH } 7.0 .\end{array}$} \\
\hline
\end{tabular}


Actinomadura, Micromonospora and Actinoplanes sp. They have been shown to be highly active against various anaerobic bacteria, mycoplasma, Gram-positive bacteria and fungi. This biologically potent family of antibiotics consists of cervinomycins, ${ }^{12)}$ lysolipin, ${ }^{10)}$ albofungin, ${ }^{3)}$ actinoplanones, ${ }^{13,14)}$ (simaomicins, LL-D42067) ${ }^{5,6,15)}$ and now Sch 42137 all of which possess a basic hexacyclic structure having xanthone and isoquinoline moieties.

\section{Acknowledgments}

The authors with to thank Dr. W. CulLEN (Pfizer) for a sample of albofungin and Dr. Borders (Lederle) for a sample of LL-D42067.

\section{References}

1) Makkar, N. S. \& T. Cross: Actinoplanetes in soil and on plant litter from freshwater habitats. J. Appl. Bacteriol. 52: $209 \sim 218,1982$

2) LeChevalieR, M. P.: Identification of aerobic actinomycetes of clinical importance. J. Lab. Clin. Med. 71:934 944, 1968

3) Liu, W.-C.; W. P. Cullen \& K. V. RaO: BA-1 80265: A new cytotoxic antibiotic. Antimicrob. Agents Chemother. -1962: $767 \sim 771,1963$

4) Gurevich, A. I.; M. G. Karapetyan, O. A. Kiseleva, T. A. Koloditskaya, M. N. Kolosov, V. V. Onoprienko, B. V. Rozynov, I. D. Ryabova, G. M. Smirnova, I. B. Sorokina \& A. M. Zyakun: Chemistry of albofungin. I. Antibiotics albofungin and chloroalbofungin. Antibiotiki 17: $771 \sim 774,1972$

5) Lee, T. M.; D. B. Borders, G. T. Carter, M. HertZ \& J. P. Kirby: LL-D42067 $\alpha$ and $\beta$, novel antibacterial and antiprotozoal agents: Isolation, characterization and structure determination. Program and Abstracts of the 26th Intersci. Conf. on Antimicrob. Agents Chemother., No. 222, p. 136, New Orleans, Sept. $28 \sim$ Oct. 1, 1986

6) LeE, T. M.; G. T. CARTER \& D. M. Borders: Structure determination of samaomicins $\alpha$ and $\beta$, extremely potent, novel anticoccidal agents produced by Actinomadura. J. Chem. Soc. Chem. Commun. 1989: 1771 1773, 1989

7) Harada, N. \& K. NaKanishi: Circular Dichroic Spectroscopy Exciton Coupling in Organic Stereochemistry. University Science Books, 1983

8) ONOPRIENKo, V. V.; Y. P. KoZ'MIN \& M. N. Kolosov: Chemistry of albofungin. XVI. Revised structure of albofungin and chloroalbofungin. Bioorg. Khim. 4: 1418 1422, 1978

9) Gurevich, A. I.; T. N. Deshko, G. A. Kogan, M. N. Kolosov, V. V. Kudryashova \& V. V. Onoprienko: The stereochemistry of albofungin. Tetrahedron Lett. 1974: 2801 2804, 1974

10) Dobler, M. \& W. KeLler-Schierlein: Metabolites of microorganisms. 162 nd communication. The crystal and molecular structure of lysolipin I. Helv. Chim. Acta. 60: 178 185, 1977

11) Cooks, R. G.; J. H. Beynon, R. M. Caprioli \& G. R. Lester: Metastable Ions. Elsevier, 1973

12) Ōmura, S.; A. NAKAGAWA, K. Kushida \& G. LuKaCs: Structure of cervinomycin, a novel antianaerobic antibiotic. J. Am. Chem. Soc. 108: 6088 6089, 1986

13) Kobayashi, K.; C. Nishino, J. Ohya, S. Sato, T. Mikawa, Y. Shiobara \& M. Kodama: Actinoplanones A and B, new cytotoxic polycyclic xanthones from Actinoplanes sp. J. Antibiotics 41: 502 511, 1988

14) Kobayashi, K.; C. Nishino, J. Ohya, S. Sato, T. Mikawa, Y. Shiobara \& M. Kodama: Actinoplanones C, D, E, F and G, new cytotoxic polycyclic xanthones from Actinoplanes sp. J. Antibiotics 41: 741 750, 1988

15) Maiese, W. M.; J. Korshalla, J. Goodman, M. J. Torrey, S. Kantor, D. P. Labeda \& M. Greenstein: Simaomicin (LL-D42067), a novel antibiotic from Actinomadura madurae. I. Taxonomy, fermentation and biological activity. J. Antibiotics 43: $1059 \sim 1063,1990$ 